\title{
Optimizing Return on Assets through Investment in Property, Plant and Equipment: Evidence from Listed Nigerian Manufacturing Companies
}

\author{
Joseph O. Udoayang, Uwem E. Uwah, Akabom I. Asuquo
}

\begin{abstract}
This study examined the extent to which investment in property, plant \& equipment (PPE) made by listed manufacturing companies in Nigeria relate with the return on assets (ROA). The non-usage of composite appraisal techniques, other than traditional budgeting techniques was seen as a major problem of investment decisions on PPE. The study adopted the quantitative panel methodology of the ex post facto and correlational research design. Secondary data were extracted from the fact books of the Nigerian Stock Exchange for the period, 2013 - 2018. The number of manufacturing companies listed in the Stock Exchange during this period was 83, which was also taken as the population of the study. The sample used in the study was 69. Three hypotheses were tested at 0.05 level of significance. Multiple and simple regression analyses were used on the data collected, to find the relationship between the independent and dependent variables. The hypotheses tested indicated in the findings that property, plant and equipment had a significant relationship with return on assets of listed manufacturing firms in Nigeria when there is a joint relationship between variables of property, plant \& equipment (PPE) and return on asset (ROA). Based on the findings and conclusion, it was recommended that management of manufacturing companies should ensure a holistic use of all techniques, exploring the real and growth options analyses as well as portfolio management techniques involving productive non-current assets, to earn the benefit of return on assets invested.

Keywords: Property, Plant and Equipment; Optimum Return on Assets; Capital investment; Manufacturing companies.
\end{abstract}

\section{I.INTRODUCTION}

Capital investment in property, plant and equipment as noncurrent assets require that adequate returns on the investment are realized at the optimum level. The Nigerian economic environment is a growing one, and for a growing economy to have a place in the comity of nations, the real sector must be developed and sustained. It is apparent that manufacturing is the pivot of the real sector of an economy, and it goes with capital assets. Capital assets have deferred expenses and determine the production capacity of a manufacturing firm. Such assets have cash outlay at the initial point of investment, but the benefits accrue over a long time period. It is the strategic investments which have long-term commitments of corporate policy that enhances particular technologies, products, and markets (Desai, Wright \& Chung, 2012).

Revised Manuscript Received on June 13, 2020.

* Correspondence Author

Joseph O. Udoayang, Department of Accounting, Faculty of Management Science, University of Calabar, Nigeria. Email: josephudoayang@yahoo.com

Uwem E. Uwah*, Department of Accounting, Faculty of Management Science, Akwa Ibom State University, Obio Akpa Campus, Nigeria. Email: uwemuwah@gmail.com.+2348033380401.

Akabom I. Asuquo, Department of Accounting, Faculty of Management Sciences, University of Calabar, Nigeria. Email: xyz3@blueeyesintlligence.org

(C) The Authors. Published by Blue Eyes Intelligence Engineering and Sciences Publication (BEIESP). This is an open access article under the CC BY-NC-ND license (http://creativecommons.org/licenses/by-nc$\mathrm{nd} / 4.0 /)$
Investment in property, plant and equipment should be painstaking and holistic in nature because the funds to be committed are normally huge and the decision, irreversible. The benefits of the investment will be seen in the firm, though not immediately, but in the future. As projects to be undertaken are, by their very nature, risky, it then requires the use of risk analysis models for evaluation, in addition to capital budgeting techniques for investment decisions to be made today for the future of the firm. It therefore becomes imperative that comprehensive approach, using traditional discounted techniques, real options analysis and modern portfolio management theory, be used to ascertain the best capital expenditure decision for the firm.

The major problem encountered by firms on investing in PPE is the passive ability to select the investments that would give optimum returns on investment because of ignoring environmental, financial and technological variables which would have aided the firm's optimum returns on investment in the long run.

This research was built on the works of earlier authors, such as McConnel and Muscarella (1985); (Agboh (2011); (Olatunji and Adegbite (2014); Boasson and Boasson (2012); Hertz (2016), and others who worked on the application of modern portfolio theory to financial and capital budgeting decisions as well as risk analysis in capital investments. There was a gap created in the studies earlier made on the subject-matter of capital investment on PPE and the relationship it has with the optimal return on the operating assets. This gap is what study seeks to fill.

The main objective of this research was to investigate the nature and extent of the relationship between investment in property, plant and equipment (PPE) and return on assets (ROA) of listed manufacturing firms in Nigeria. The specific objectives include to examine the relationship between investment in property, plant and equipment (PPE) and fixed assets turnover (FAT); The nature and extent of relationship between the purchases price of assets (PPA); The relationship between overhauling costs of assets and the operating income (OIC); The effect of project risk in PP\&E investment on the overall return on assets (ROA) of Nigerian manufacturing companies listed on the Nigerian Stock Exchange.

\section{II.CONCEPTUAL AND EMPIRICAL REVIEW}

The basic objective of doing business is cash flows generation that would add up to make profit for the owners of the business. Albrecht, Stice, Stice and Swain (2008) opine that strategy formulation and implementation is the hall-mark of profitable business operation.

Published By: Blue Eyes Intelligence Engineering \& Sciences Publication 


\section{Optimizing Return on Assets through Investment in Property, Plant and Equipment: Evidence from Listed Nigerian Manufacturing Companies}

The strategy includes use of minimum cost of capital, actualization of positive net present values and a whole lot of other business strategies, aimed at long-term sustenance of the firm.

From the work of many authors in accounts and finance, it is entrenched that strategic decisions involve substantial allocation of funds which are either internally sourced or borrowed from outside the firm. These funds are also mind, the concept of capital investment which Horngren (2004) defined as the total amount of money or other resources owned or used by an individual or a company to acquire future benefits or income.

Investment in capital is done with the expectation of recovering it with an added value, which is called profit in accounting and return on investment will be determined by how much profit is made. It therefore becomes imperative that sound investment decisions be made to have optimum returns on investment. Unfortunately, most companies at this age and time still depend on intuition and judgement without scientific analysis in making investment decisions (Udoayang \& Asuquo, 2007).

Pandey (2009) emphasized that capital expenditure involving non-current assets such as PP\&E must make use of capital budgeting techniques. This informs the decision on which of the contesting projects would give the highest yield to return on the investment over a time period.

Hansen and Mowen (1996) assert that capital budgeting is not the only criterion used in making capital investments. This is a paradigm shift from the old order of seeing capital budgeting techniques as the only long-term investment appraisal strategy. As put by Schwarz (2000), capital investment decisions are made using other criteria such as real options analysis, portfolio analysis, capital assets pricing model (CAPM), and many others.

Horngren (2014) further distinguished capital as operational asset used for a long time period for the creation of wealth or further assets while capital budgeting involves the plan to invest in assets on a long-time basis in a manner that would profit the company. Capital investment is simply the acquisition of capital asset, of which the acquisition of $P P \& E$ is a major aspect.

Ojo (2004) maintained that planning for fixed assets replacement is a factor which manufacturing companies must be sensitive at. If plants and equipment are used for a period beyond its effective life, excessive expenditure on repairs would come in and would cause the returns to be less than the expenditure. Where machines are obsolete owing to technological changes and new product designs, it is always needful to replace such assets in time so that production and sales are not affected negatively. This implies that research and development (R\&D) must be part of strategy to optimize return on assets, wherewith new and better ways of production should be learnt.

Adeboye (2016) opined that optimum return on assets can be achieved when the investment in the required PPE will ensure better working conditions and safety to the employees. This is a type of capital investment that cares for the better working conditions of the employees and provision of facilities to the workers, which in turn optimizes the return on investment.

To the management, incorporating financing decision into investment decision, according to Isom (1995) is what aids management to optimize returns on investment. In financing committed to actions over a long-term period. This brings to

assets, Albrecht et al (2008) bring forth the concept of 'optimal' solutions to emphasize the simultaneous issues of meeting multiple objectives, such as maximization of benefits while at the same time minimizing costs. Minimizing debt cost while at the same time maximizing tax benefits are also salient issues for consideration in asset financing involving property, plant and equipment.

Farooq and Sajid (2015) add that from the view point of quantitative analysis, the success of investment in noncurrent assets will depend on the future cash savings, which are the expected cash flows as they relate to the initial cash outlay made during the investment. This concept goes along with the value of money as it pertains to time. This is to enhance proper evaluation of future cash flows.

Every project, according to Brigham and Ehrhardt (2014) has a risk attached to it. For a project to be successful, there must be value creation through the return it generates that is commensurate with the size and risks of the asset involved. Lucey (2000) adds that a company's success is measured through its ability to select value- adding projects through thorough analysis and avoid value-minimizing projects. Peterson and Fabozzi (2002) assert that project risk manifests in the extent to which the future cash flows and their value is uncertain. Project's incremental cash flow is a pivot for estimation and this incremental cash flow are made up of operating cash flows which include change in the revenue profile, taxation and other expenses of the firm on the one hand, and investment cash flows, made up of the project's acquisition and disposal of assets, on the other hand. The estimation of these future cash flows is arrived at after an evaluation is made, using the project's discount rate which reflects its uncertainty, using alternative evaluation techniques. These assertions are very true of investment in PPE.

Evans (2006) however posit that for any meaningful evaluation of investment project, risk must first be analyzed to see the difference between expected and actual cash flows, considering what amount is involved and also the timing of the cash flows. According to them, it is expedient for managers to incorporate risk into their calculation by discounting future cash flows with the use of higher discount rate, or expecting an annual return which is higher, from the project. Both will however give a greater cash flow risk to the firm. Elaborating risk and cash flows, Pandey (2009) opine that the benefits the firm will reap in the future and what it will cost to invest in a given project now is the major concern of management when coping with uncertainty. This uncertainty is widespread with peculiarity on the investment type and the prevailing circumstances in the operating industry. Peterson and Fabozzi (2002) list five conditions which uncertainty can result from, in a firm. These are economic and market conditions. Others are taxes, interest rates and exchange rates differences in international market. These uncertainties affect future cash flows, and for a firm to choose projects that will enhance its long-term value, it is reasonable that assessment is done on the assets that relate with the cash flows of the project. Measuring risks, therefore works hand in gloves with evaluation of capital projects. Investment in PP\&E requires the investor to estimate the required rate of return for consideration of the risk assessment of the projects.

Published By:

Blue Eyes Intelligence Engineering \& Sciences Publication

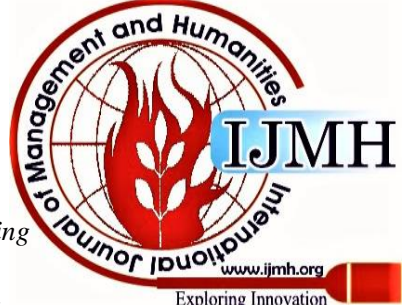


According to Hertz (2016), this is the investors' expected future returns as a payoff to their investment. The shareholders and other suppliers of capital would certainly demand to be compensated for risk-taking. They utilize the opportunity to invest in a particular project at their disposal and have good returns, or invest their funds elsewhere. This gives consideration to the opportunity cost of investment.

It is worthy of note that if the decision to invest in PP\&E brings returns of a greater value than the cost of capital, then there is value-addition to the firm. The additional return required as compensation for investors in view of the risk they take is termed 'risk premium'. To assess the risk of a project, it must be understood that the firm's assets are obtained as a result of its previous capital expenditure decisions. The firm as a market is seen as a collection or portfolio of projects. As a new project is added to its portfolio, two types of risks will emanate; the risk of the additional project and the risk of the firm (entire portfolio). In PP\&E investment, both risks are assessed to evaluate the known required rate of return on existing assets, before decision is made to acquire new assets (McConnel \& Muscarella, 1985).

Olatunji and Adegbite (2014) studied the effect of investment in fixed assets on profitability of selected firms in Nigeria. The problem investigated in this study was nonutilization of fixed assets by companies in Nigeria to boost profitability. The methodology adopted in this study was the gathering of cross-sectional data from the annual reports of the sampled companies for a period covering 2000 to 2012. Regression analysis technique was used to measure the effect of independent variables on dependent variable. Results showed that investment in fixed assets has significant positive relationship to the performance of the sampled firms. This result implies that the increase in acquisition of machinery leads to increase in return on investment, which in effect has strong significance in the increase in firm's value in the long run. The gap however created in this study was the lack of methodology in making capital expenditure decisions that will enhance the acquisition of machinery that would lead to the envisaged increase in the ROI.

Desai, Wright and Chung (2012) in their work submitted that the major aspect of capital investment in PP\&E is the cost of capital. Capital asset pricing model (CAPM) is used for the estimation of cost of capital, which of course managers must know what the market risk premium is. CAPM therefore helps the company to assess the riskiness of its investment opportunities. This is a practical tool which helps managers to make sound capital budgeting decisions, while at the same time using the firm's resources efficiently. Empirically, CAPM is preferred as the model to determine the cost of capital, arising from the studies made by Black, Jensen and Scholes (1972). It is still being largely argued by scholars that CAPM, as though theoretically, is not good enough to provide a precise estimate of the cost of capital. To calculate CAPM, one must first of all know the beta value.

We can calculate the beta values in various ways, using the formula,

$$
R S=R f+\beta(R M-R f) .
$$

1. By making it the subject of the formula. Thus:

$$
\beta=\frac{R S-R f}{R M-R f}
$$

2. By the use of regression analysis:

Where,

$$
\beta=\frac{n \Sigma x y-\Sigma x \Sigma y}{n \Sigma x^{2}-(\Sigma x)^{2}}
$$

$$
\begin{aligned}
& x=R M-R f \\
& y=R S-R f
\end{aligned}
$$

3. By use of expected return analysis.

Where:

$$
\frac{\Sigma P(R p-\overline{R p})(R m-\overline{R m})}{\Sigma P(R m-\overline{R m})^{2}}
$$

$$
\begin{aligned}
& \mathrm{Rp}=\text { forecast return from the project } \\
& \overline{R p}=\text { expected return from the project } \\
& \mathrm{Rm}=\text { forecast return from the market } \\
& \overline{R m}=\text { expected return from the market } \\
& \mathrm{P}=\text { probability distribution. }
\end{aligned}
$$

4. By using standard deviation analysis.

Where:

$$
\beta=\frac{\sigma P \times r}{\sigma m}
$$

$$
\begin{aligned}
\sigma P & =\text { standard deviation of the project } \\
\sigma m & =\text { standard deviation of the market } \\
r & =\text { coefficient of correlation. }
\end{aligned}
$$

Be it as it may, Jagannathan and Miers (2001) opine that for calculating the cost of capital using the CAPM, necessarily the firm should know the numbers for the market risk premium and also the project's beta. But empirical studies by Brealy \& Myers (2000) show that managers may not even know what the market risk premium is, since the use of historical average returns for a long time period has been the common practice till now. There might have been flaws in arriving at the historical returns, thereby giving a false measure of shareholders' earnings expectation. This is not concise.

The approach to be used that may be perfect to calculating the cost of capital for project appraisal, according to Jagannathan and Miers (2001) should therefore be the use of a discount rate (hurdle rate) that is higher than the cost of capital, but not directly related to it.

The organization's supply of capital is limited and this is a major constraint when deciding whether to buy an asset or not. Companies cannot take up all projects with positive net present value at the same time, if there are constraints. Therefore, by deciding to have some projects to wait, the firm takes up the option to undertake even more attractive project that will minimize risk and increase profitability. In this case, acquiring property, plant and equipment that can give optimum return on investment is preferred. As suggested by McDonald (1999) the hurdle rate that is substantially higher than the cost of capital should be used in computing net present values in order to account for the value of the option to wait, if it is essential.

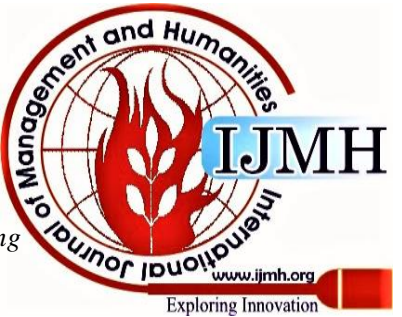




\section{Optimizing Return on Assets through Investment in Property, Plant and Equipment: Evidence from Listed Nigerian Manufacturing Companies}

As could be seen in Fig.1 below, manufacturing companies desire to have profitability while reducing risk on investment in property, plant and equipment. Optimum financing and investing decisions must be carried out by management in acquiring the non-current assets. The cost of these assets (PPE) has to have a combination of the purchase price and the deferred assets, which are expenditure made in advance which has not yet been consumed until a large number of reporting periods have passed (Bragg, 2019).

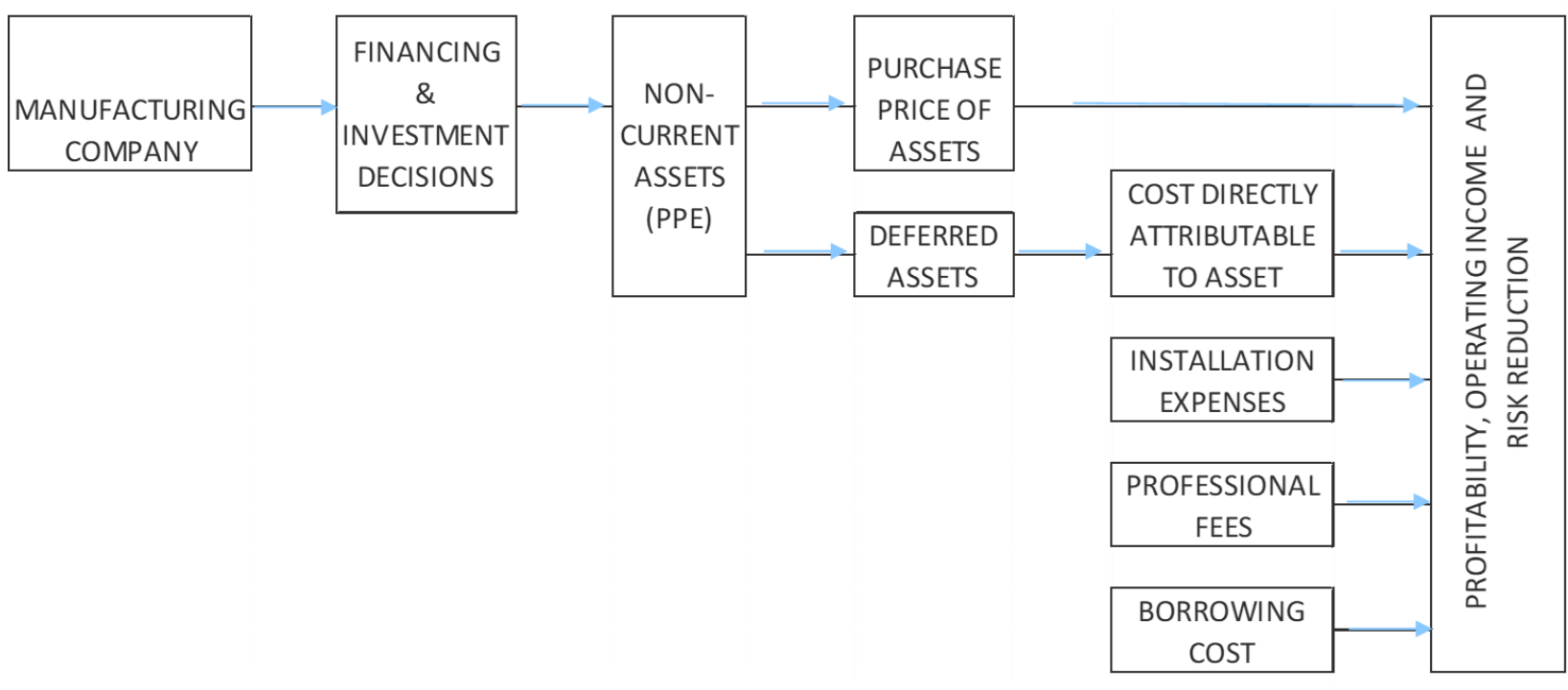

Figure 1: Conceptual framework, developed by Researchers (2019)

order to estimate the extent to which the value to the factors are related. The goal of this design was to measure the relationship between return on assets in Nigerian manufacturing companies and their relationship with investment in non-current asset using property, plant and equipment. This methodology was used in analyzing secondary (panel) data collected and collated from the Nigerian Stock Exchange (NSE) Fact Books and the published financial statements of these companies for the period, $2013-2018$.

B. Method of data analysis: Simple and multiple regression analyses were adopted for this study, to find out the relationship between companies' investment in property, plant and equipment, and return on assets. Hypotheses were equally developed to test the proxies of the independent and dependent variables at 0.05 level of significance. The decision rule was to accept the null hypotheses $\left(\mathrm{H}_{0}\right)$ if the significant value $(\mathrm{p})$ is greater than the 0.05 level of alpha at 68 degrees of freedom and reject the result if otherwise.

C. Model specification: Linear regression analysis was used to find the relationship between firms' investment in in property, plant and equipment (PPE) and return on assets (ROA). Return on asset as a dependable variable on the cost of property, plant and equipment was measured by profit after tax (PAT), operating income (OIC) and fixed asset turnover (FAT). The regression models used in testing the hypotheses

were: examination of independent and dependent variables in retrospect for the measurement of two factors in

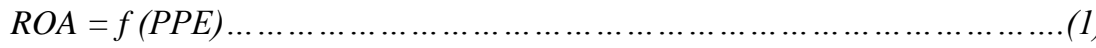

$$
\begin{aligned}
& \mathrm{Y}=\alpha+\beta_{1} x_{1}+\beta_{2} x_{2}+\mu
\end{aligned}
$$

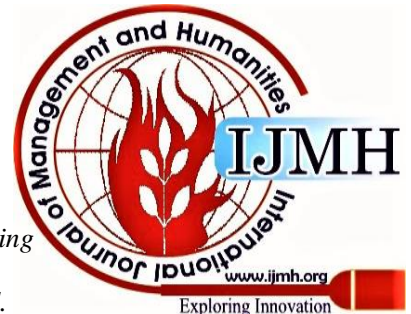


Where ROA $=\mathrm{Y}$, the dependent variable, and $\beta_{1}, \beta_{2}$, are the coefficients of the independent variable (PPE), which has purchase price of asset (PPA) and overhaul cost, (DA) as proxies represented by $X_{1}, X_{2}$ respectively. Equation (2) then becomes:

$\mathrm{PAT}=a_{0}+\beta_{1} \operatorname{LogPPA}_{i t}+\beta_{2} \log A_{i t}+\mu_{i t}$
$\mathrm{OIC}=a_{0}+\beta_{1} \operatorname{LogPPA}_{i t}+\beta_{2} \log D A_{i t}+\mu_{i t}$
$\mathrm{FAT}=a_{0}+\beta_{1} \operatorname{LogPPA}_{i t}+\beta_{2} \log D A_{i t}+\mu_{i t}$

Where: $\mathrm{i}=$ Company $(1,2,3 \ldots \ldots . .69)$, and $\mathrm{t}=$ pooled data for the time period (six years).

$a_{0}=$ the intercept, and $\beta_{1} \log P P A_{i t}+\beta_{2} \log D A_{i t}$ are the natural logarithms of purchase price of asset (PPA) and overhaul cost of asset (DA). These are proxies of PPE, the independent variable, which shows the kind of relationship existing between dependent and independent variables and $\mu=$ error term.

\section{V.RESULTS AND DISCUSSION OF FINDINGS}

The data collected were analyzed in line with the research questions and the formulated hypotheses, using the Statistical Package for Social Science (SPSS) V.20 at 5\% level of significance.
Hypothesis 1: There is no significant relationship between property, plant \& equipment (PPE) and fixed asset turnover (FAT).

Table 1: Descriptive statistics for PPA, DA and ROA

\begin{tabular}{ccc|c|c|cc|ccc|c}
$\begin{array}{c}\text { Research } \\
\text { Variables }\end{array}$ & N & $\begin{array}{c}\text { Minimum } \\
\text { Statistic }\end{array}$ & $\begin{array}{c}\text { Maximum } \\
\text { Statistic }\end{array}$ & $\begin{array}{c}\text { Mean } \\
\text { Statistic }\end{array}$ & $\begin{array}{c}\text { Std. Deviation } \\
\text { Statistic }\end{array}$ & Statistic & Std. Error & Statistic & Std. Error \\
\hline PPA & 69 & -34.08 & 12.14 & 1.3582 & 4.96382 & -5.230 & 0.289 & 39.152 & 0.570 \\
DA & 69 & 0 & 7.06 & 1.6958 & 1.6958 & 1.682 & 0.289 & 3.796 & 0.570 \\
ROA & 69 & 1.29 & 21.57 & 7.5091 & 3.65617 & 1.296 & 0.289 & 2.718 & 0.570 \\
\hline
\end{tabular}

Hypothesis 2: There is no significant relationship between purchase price of asset (PPA) and profit after tax (PAT). Hypothesis 3: There is no significant relationship between overhaul cost of assets (DA) and operating income (OIC). Source: SPSS Data output by researchers (2019)

The data in Table 1 shows the descriptive statistics for the variables of this study. Sample size of sixty-nine (69) manufacturing companies were used and the minimum values of 34.08 and 0.00 were obtained for PPA and DA respectively, while the minimum value for ROA was computed as 1.29. Maximum values of 12.14 and 7.06 were the statistics for PPA and DA respectively, while the maximum for ROA was computed to be 21.57. The mean of 7.5091 was obtained for ROA, while PPA and DA had 1.3582 and 1.6958 respectively. The standard deviation which measures how much the variables differ from the mean value for the distribution were computed as 4.9638 and 1.6958 for the independent variables (PPA \& DA) respectively, while that of $\mathrm{ROA}$, the dependent variable, was calculated as 3.6562. For the measure of skewness, which deals with the fitness of data distribution, ROA was found to be 1.296 and DA was 1.682. However, the calculation of this measure for PPA showed that it was skewed to the left (skewness less than 0). Kurtosis, a measure of the spread of the data (normality of data distribution) for PPA and DA were 39.152 and 3.796 respectively, while that of ROA was calculated as 2.718 . This showed that all the variables were greater than 0 . In any case, the result of skewness and kurtosis is an indication that the variables used in this study did not follow a normal distribution.

Table 2: Simple regression analysis of the relationship between property, plant \& equipment (PPE) and fixed asset turnover (FAT)

\begin{tabular}{|c|c|c|c|c|c|c|c|c|c|}
\hline \multirow{2}{*}{ Model } & \multirow{2}{*}{$\mathrm{R}$} & \multirow{2}{*}{ R Square } & \multirow{2}{*}{$\begin{array}{l}\text { Adjusted } \\
\text { R Square }\end{array}$} & $\begin{array}{r}\text { Unstar } \\
\text { Coe }\end{array}$ & $\begin{array}{l}\text { derdized } \\
\text { ficient }\end{array}$ & $\begin{array}{c}\text { Standardized } \\
\text { Coefficient }\end{array}$ & \multirow{2}{*}{$\mathrm{t}$} & \multirow{2}{*}{ Sig. } & \multirow{2}{*}{ Result } \\
\hline & & & & B & $\begin{array}{c}\text { Standard } \\
\text { Error }\end{array}$ & Beta & & & \\
\hline PPE & 0.12 & 0.000 & -0.015 & -0.006 & 0.058 & -0.012 & -0.095 & 0.925 & $\begin{array}{l}\text { Insignificant } \\
\text { (Accept } \mathrm{HO} \text { ) }\end{array}$ \\
\hline
\end{tabular}

Source: SPSS Data output by researchers (2019)

From table 2, null hypothesis 1 was tested. Fixed asset turnover (FAT) is the proxy of return on asset (ROA), the dependent variable. $\mathrm{R}$ square and the adjusted $\mathrm{R}$ square values both measure the proportion of the variation in the dependent variable.

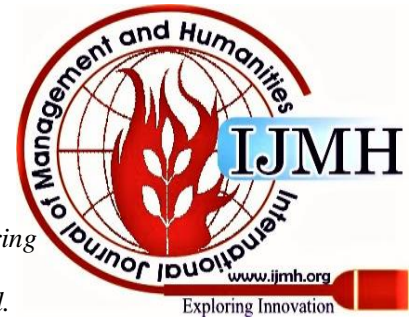




\section{Optimizing Return on Assets through Investment in Property, Plant and Equipment: Evidence from Listed Nigerian Manufacturing Companies}

The adjusted $\mathrm{R}$ square specifically shows the modification for the limitation of $\mathrm{R}$ square, and this measures the model's fitness. The $\mathrm{R}$ square value is 0.000 while the adjusted $\mathrm{R}$ square value is calculated as -0.015 . This implies that the

independent variable (PPE) takes less than $1 \%$ variation on fixed asset turnover, a proxy of return on asset (ROA).

However, the multiple correlation coefficient (R) shows a value of 0.12 , an insignificant $12 \%$ relationship between the independent and dependent variables. The $\mathrm{R}$ square value of 0.000 clearly shows a non-existing relationship between the two variables. This table further shows a p-value of 0.925 which is greater than the 0.05 alpha value in this study. We therefore had to accept the null hypothesis 1, indicating that there is no significant relationship between PPE and FAT, a proxy of ROA.

Table 3: Simple regression analysis of the relationship between purchase price of asset (PPA) and profit after tax

\begin{tabular}{|c|c|c|c|c|c|c|c|c|c|}
\hline \multirow{4}{*}{ Model } & \multirow{4}{*}{$\mathrm{R}$} & \multirow{4}{*}{ R Square } & & \multicolumn{3}{|c|}{ (PAT) } & & & \\
\hline & & & \multirow{3}{*}{$\begin{array}{l}\text { Adjusted } \\
\text { R Square }\end{array}$} & $\begin{array}{r}\text { Unstar } \\
\text { Coe }\end{array}$ & $\begin{array}{l}\text { derdized } \\
\text { ficient }\end{array}$ & $\begin{array}{c}\text { Standardized } \\
\text { Coefficient }\end{array}$ & \multirow{3}{*}{$\mathrm{t}$} & \multirow{3}{*}{ Sig. } & \multirow{3}{*}{ Result } \\
\hline & & & & & Standaro & & & & \\
\hline & & & & B & Error & Beta & & & \\
\hline PPA & 0.159 & 0.025 & 0.011 & 0.044 & 0.033 & 0.159 & 1.319 & 0.192 & $\begin{array}{l}\text { Insignificant } \\
\text { (Accept HO) }\end{array}$ \\
\hline
\end{tabular}

Source: SPSS Data output by researchers (2019)

Data on table 3 show the relationship between purchase price of asset (PPA), a proxy of PPE and profit after tax (PAT), a proxy of ROA. These data are also used in testing hypothesis 2. The beta value of 0.159 indicates a contribution of an approximate value of $16 \%$ by PPA to profit after tax in the firms under study. This supposes that there is positive correlation coefficient, though the relationship is relatively on the lower side. But the p-value of 0.192 shows that it is greater than 0.05 alpha value, thereby rejecting the null hypothesis 2 . Therefore, the purchase price of assets has no significant relationship with profit after tax of the Nigerian manufacturing companies.

Table 4: Simple regression analysis of the relationship between overhaul cost of assets (DA) and operating income

\begin{tabular}{|c|c|c|c|c|c|c|c|c|c|}
\hline \multirow{4}{*}{ Model } & \multirow{4}{*}{$\mathrm{R}$} & \multirow{4}{*}{$\mathrm{R}$ Square } & \multirow{4}{*}{$\begin{array}{l}\text { Adjusted } \\
\text { R Square }\end{array}$} & \multicolumn{3}{|c|}{ (OIC) } & & & \\
\hline & & & & $\begin{array}{r}\text { Unsta } \\
\text { Coe }\end{array}$ & $\begin{array}{l}\text { erdized } \\
\text { icient }\end{array}$ & $\begin{array}{c}\text { Standardized } \\
\text { Coefficient }\end{array}$ & \multirow{3}{*}{$\mathrm{t}$} & \multirow{3}{*}{ Sig. } & \multirow{3}{*}{ Result } \\
\hline & & & & & Standard & & & & \\
\hline & & & & B & Error & Beta & & & \\
\hline DA & 0.813 & 0.661 & 0.656 & 0.863 & 0.075 & 0.813 & 11.436 & 0.000 & $\begin{array}{l}\text { Significant } \\
\text { (Reject HO) }\end{array}$ \\
\hline
\end{tabular}

Source: SPSS Data output by researchers (2019)

From table 4, the relationship between overhaul cost of assets and operating income are analysed. Overhaul costs of assets or major inspection costs as a proxy of PPE are indicated as capital expenditure made in the process of restoring and maintaining physical assets of long-term nature. This is based on null hypothesis 3. The table shows a Beta value of 0.813 which is about $81 \%$ of the total contribution of overhauling costs of PPE to the firm's operating income. This data is the same as multiple correlation coefficient (R), which shows a high correlation index. The $\mathrm{R}$ square value of 0.661 which connotes about 66\% relationship between the independent and dependent variables were also calculated. With the adjusted $\mathrm{R}$ square value of 0.656 , it is indicated that the independent variable in this test explains about 66\% variation on the dependent variable. The sig. value shows 0.000 which is less than the alpha value of 0.05 , therefore, the null hypothesis four is rejected. This implies that costs of overhauling the non-current assets in Nigerian manufacturing companies have significant relationship with operating income.

Table 5: Summary for the Regression of PPE with ROA

\begin{tabular}{cccccc}
\hline Model & R & R Square & $\begin{array}{c}\text { Adjusted } \\
\text { R Square }\end{array}$ & Std. Error of the Estimate & Durbin-Watson \\
\hline 1 & 0.644 & 0.415 & 0.397 & 2.383960 & 1.820 \\
\hline
\end{tabular}

Source: SPSS Data output by researchers (2019)

From Table 5, a regression square (R2) of 0.415 was calculated, which shows that $41.5 \%$ was the contribution of both independent variables (PPA and DA) on the dependent variables (PAT, OIC, FAT) which together

measured the ROA in totality.

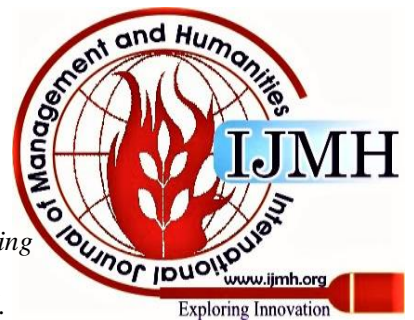


The multiple correlation coefficient of 0.397 was obtained, which means that $39.7 \%$ of the variation in return on assets

were accounted for by joint influence of PPA and DA.

Table 6: ANOVA Result associated with multiple regressions on the joint relationship between variables of property, plant \& equipment (PPE) and return on asset (ROA)

\begin{tabular}{|c|c|c|c|c|c|c|c|c|}
\hline Model & $\begin{array}{c}\text { Sum of } \\
\text { Squares }\end{array}$ & df & $\begin{array}{l}\text { Mean of } \\
\text { square }\end{array}$ & $\mathbf{F}$ & $\mathbf{R}$ & $\mathbf{R 2}$ & p-value & Result \\
\hline Regression & 68.600 & 1 & 68.600 & \multirow{3}{*}{5.469} & \multirow{3}{*}{0.275} & \multirow{3}{*}{0.075} & \multirow{3}{*}{0.022} & \multirow{3}{*}{ Signifcant } \\
\hline Residual & 840.397 & 67 & 12.543 & & & & & \\
\hline Total & 908.996 & 68 & & & & & & \\
\hline
\end{tabular}

Source: SPSS Data output by researchers (2019).

Table 6 shows a multiple correlation between all proxies of the dependable variable with the independent variable. A multiple correlation coefficient (R) of 0.275 was calculated, showing a high correlation. $\mathrm{R}$ squared value of 0.075 was realized which indicates that the proxies of the independent variable combined contributes about $7.5 \%$ to the return on assets of the Nigerian manufacturing companies. The table also reveals a p-value of 0.022 which is less than the chosen alpha level of 0.05 , thereby rejecting our hypothesis four. This means that project risks involved in property, plant \& equipment's investment have significant effect on companies return on assets.

\section{CONCLUSION AND RECOMMENDATIONS}

In this study, the findings reveal that fixed asset turnover and profit after tax, as proxies of return on assets do not have significant relationship with investment in property, plant and equipment of manufacturing companies in Nigeria. However, overhauling costs of non-current assets by these companies, another proxy of PPE has a significant relationship with operating income, aa proxy of return on assets. More so, when the analysis of variance, ANOVA, associated with multiple regression on the joint relationship of the variables of independent and dependent variables was conducted the findings showed a significant relationship.

It was concluded that there is generally a significant relationship between return on assets and investment in property, plant and equipment by manufacturing companies in Nigeria who are listed in the Nigerian Stock Exchange.

It was therefore recommended that since project risks has been found to have significant effect on return on assets, management of manufacturing companies in Nigeria should ensure that proper risk analysis be conducted before a decision is made to invest in the non-current assets of PP\&E. Also, management of manufacturing companies should ensure a holistic use of all techniques, exploring the real and growth options analyses as well as portfolio management techniques involving non-current productive fixed assets, to earn the benefit of return on assets invested.

\section{ACKNOWLEDGEMENTS}

The researchers sincerely recognize and thank all individuals, too many to say publicly, who have contributed directly or indirectly towards the achievement recorded during the preparation of this manuscript, most especially management and staff of the selected manufacturing companies, the Federal Office of Statistics, Nigeria, the Central Bank of Nigeria, Investments and business analysts and Nigerian Stock Exchange.

\section{REFERENCES}

1. Adeboye, M. (2016). Cost management as effective tool for decision-making process. The Nigerian Accountant: Journal of the Institute of Chartered Accountants of Nigeria, 49 (3), 30-44.

2. Agboh, C. I. (2011). Utilization of capital budgeting as an optimal tool for investment analysis in manufacturing companies in Enugu and Anambra states. (Unpublished doctoral thesis), University of Nigeria, Nsuka.

3. Albrecht, W. S., Stice, E. K ., Stice, J. D. \& Swain, M.R. (2008). Accounting: Concepts and applications (10th ed.). Boulevard, USA: Thomson South-western.

4. Black, F., Jensen, M. C. \& Scholes, M. (1972). The capital asset pricing model: Some empirical tests in Jensen studies in the theory of capital markets (8th ed.). New York: Praeger.

5. Boasson, V., Cheng, J. \& Boasson, E. (2012). Applying modern portfolio theory to municipal financial and capital budgeting decisions. Journal of Public and Municipal Finance, 1 (58), 837845.

6. Bragg, S. M. (2019). Management accounting best practices (12th ed.). New Jersey: John Wiley \& Sons Inc.

7. Brealy, R.A. \& Myers, S.C. (2000). Principles of corporate finance (6th ed.). Irwin, McGraw Hill.

8. Brigham, E.F. \& Ehrhardt, M.C. (2014). Financial management: Theory and practice (9th ed.). NY: South-Western Cangage Learning.

9. Desai, A., Wright, P. \& Chung, K. H. (2012). Impact of changes in strategic investments on shareholder returns: The role of growth opportunities. The Journal of Applied Business Research, 19 (1). 63-88.

10. Evans, D. A. (2006). Subject perceptions of confidence and predictive validity in financial cues. Journal of Behavioral Finance, 7 (1), 102-128.

11. Farooq, A. \& Sajid, M. (2015). Factors affecting investment decision making: Evidence from equity fund managers and individual investors in Pakistan. Research Journal of Finance and Accounting, 6 (9), 92-121.

12. Hansen, D. R. \& Mowen, M. M.(1996). Management accounting (4th ed.). New York: South-western College Publishers.

13. Hertz, D. B. (2016). Risk analysis in capital investment. Harvard Business Review Journal. Retrieved from http://hbr.org/1979/09/risk-analysis.

14. Horngren, C. T. (2014). Financial and managerial accounting (4th edition). New Jersey:Pearson Education Inc.

15. Isom, T. A. (1995). Asset financing strategies: Alternatives and comparisons (1st ed.). Connecticut: Financial Accounting Standards Board.

16. Jagannathan, R. \& Miers, I. (2001). Do we need CAPM for capital budgeting? Retrieved from https://faculty.fuqua.duke.edu.

17. Lucey, T. (2000). Management accounting. London: Bloomsbury Publishing Inc.

18. McConnel, J. J. \& Muscarella, C. J. (1985). Corporate capital expenditure decisions and the market value of the firm. Journal of financial economics, 14, (12), 399-422.

19. McDonald, R.L. (1999). Real options and rules of thumb in capital budgeting. London: Oxford University Press.

20. Ojo, C. O. (2004). Theory and practice of managerial accounting for decision making. Enugu: Rhyce Kerex Publishers.

Published By:

Blue Eyes Intelligence Engineering \& Sciences Publication

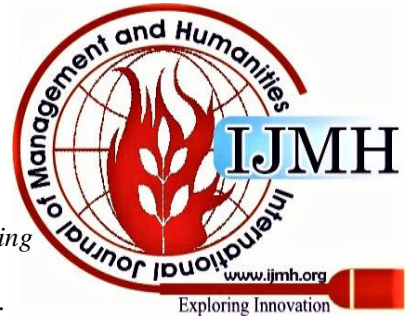


21. Olatunji, T. E. \& Adegbite, T. A. (2014). Investment in fixed assets and firm profitability: Empirical evidence from the Nigerian banking sector. Asian Journal of Social Sciences and Management Studies, 1 (3), 78-82.

22. Pandey, I. M.(2009). Financial management (9th ed.). Bombay: Vikas Publishing House Ltd.

23. Pandey, I. M.(2015). Financial management (11th ed.). Bombay: Vikas Publishing House Ltd.

24. Peterson, P. P. \& Fabozzi, F. J. (2002). Capital budgeting: theory and practice (6th ed.). Toronto: John Wiley \& Sons.

25. Schwarz, E. (2000). Real options and investment under uncertainty (1st ed.). New York: Texere publishing Ltd.

26. Udoayang, J. O. \& Asuquo, A. I.(2007). The breaking of tied ranks in investment decisions. Universite de Dschang. Interdisciplinary Journal of Arts, Social and Management Sciences. 4 (8), 183-189.

\section{AUTHORS' PROFILES}

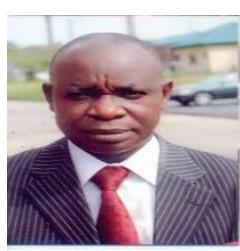

Prof. J O. Udoayang holds B.Sc., M.Sc., MBA and $\mathrm{PhD}$ degrees in Accounting. And has professional certificates: FCNA, FCCA and FIIA. $\mathrm{He}$ is a member of many professional bodies at home and abroad; and a committed community development leader. Professor Udoayang has attended many local and international conferences and had presented cutting edge research papers in

all these conferences.

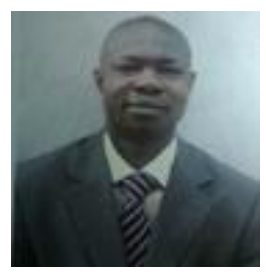

Dr. Uwem E. Uwah, is a fellow of the Institute Chartered Accountants of Nigeria and Institute of Corporate Administration of Nigeria. He holds B.Sc., M.Sc., MBA and PhD degrees in Accounting, and has several academic papers to his credit. Dr. Uwah has attended several Academic conferences, locally and internationally and currently lectures at the Akwa Ibom State University, Obio Akpa Campus, Nigeria.

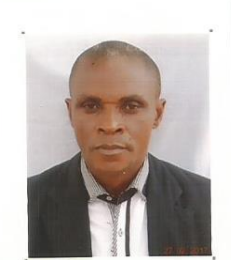

Akabom I. Asuquo, Associate Professor A. I. Asuquo holds B.Sc., M.Sc., and PhD degrees in Accounting. And has many professional certificates: ACA, FCCA and FIIA. He is a member, European Centre for Research Training and Development, UK; Member, International Research and Development Institute, Nigeria. Currently, he is the Chairman, Faculty Seminar and Research Committee. Associate Professor Asuquo has attended many local and international conferences and had presented academic papers in all these conferences. He has developed an award-winning model called Standard Magnitude Variance/Progress index, which is used in determining the financial progress of any business organization since 2006 . 